\title{
THE MEDIATING EFFECT OF STUDENT'S PERCEPTION AND SATISFACTION ON THE RELATIONSHIP OF LEARNING ENVIRONMENT AND ACCOUNTING CAREER
}

\author{
Angeline Sugiarto Yusuf ${ }^{1}$; Yenni Mangoting²; Melly Irna Natasya Hoetomo; \\ Saarce Elsye Hatane ${ }^{4}$; Hatane Semuel ${ }^{5 *}$ \\ ${ }^{1-4}$ Accounting Program, Faculty of Business and Economy, Petra Christian University \\ ${ }^{5}$ Management Program, Faculty of Business and Economy, Petra Christian University \\ Jl. Siwalankerto No. 121-131, Siwalankerto, Wonocolo, Surabaya, Jawa Timur 60236, Indonesia \\ 12angelinessyy@gmail.com; ²yenni@petra.ac.id; ${ }^{3}$ natasyahutomo@gmail.com; \\ ${ }^{4}$ elsyehat@petra.ac.id; ${ }^{5}$ samy@petra.ac.id
}

Received: 09 ${ }^{\text {th }}$ March 2021/ Revised: $14^{\text {th }}$ April 2021/ Accepted: $20^{\text {th }}$ April 2021

\begin{abstract}
How to Cite: Yusuf, A. S., Mangoting, Y., Hoetomo, M. I. N., Hatane, S. E., \& Semuel, H. (2021). The mediating effect of student's perception and satisfaction on the relationship of learning environment and accounting career.

Humaniora, 12(3), 179-189. https://doi.org/10.21512/humaniora.v12i3.7114
\end{abstract}

\begin{abstract}
The research was inspired by accounting students' failure to put their knowledge in line with their career choice in the accounting field, which in turn became a concern to higher education providers and accountant associations to be solved. The research aimed to discover accounting students' intention to be an accountant in accounting education in Indonesia. Data were gathered through a survey with questionnaires involving accounting undergraduate students of both universities and colleges of private and govern as of vocational education in Indonesia. The 311 collected questionnaires were analyzed using Partial Least Square (PLS). The research proves that the learning environment is the main factor influencing students' intention to pursue their careers in the accounting field. The learning environment as an external factor can alter either perception or perspective of accounting students concerning the accounting profession, affecting students' intention to pursue a career in the accounting field. Another finding of the research is that perception of students' beliefs built through interaction and experience of the learning environment elements can affect their satisfaction and intention to pursue a career in the accounting field.
\end{abstract}

Keywords: learning environment, student's perception, student's satisfaction, career choice

\section{INTRODUCTION}

The Industrial Revolution 4.0 era and some Artificial Intelligence(AI) applications have significant impacts on how the industry manages its functions in its organization, and the accountant profession is no exception. Information technology, which is likely to replace human role, is perceived as a threat to the accountant profession (Friedman, 2016; Gardner, 2017). The increased demand for the accounting profession and universities' minimum offer allows researchers to research the underlying motivation of accounting students' intent to be accountants. Referring to the Institute of Indonesia Chartered Accountants (IAI) data, the registered accountants are around 40.000 , whereas public accountants are about 1.000 people. The Institute of Public Accountants (IAPI) confirms this information, stating that Indonesia has only 4.000 CPA (Certified Public Accountant), much less than Thailand with $12.000 \mathrm{CPA}$. To go further, IAPI explains that of 700.000 corporate taxpayers, only around 30.000 corporates use external audits. The absence of the offer to the accountant profession is an exciting research object to conduct. The effort to identify accounting students' behavior in choosing a career after graduation can contribute to both 
university and association of professions curriculum formation.

Unlike the previous studies, the research focuses on empirically testing internal factors, which is students' behavioral aspect in the perspective of satisfaction and perception, and external factor that is learning environment, which can influence students' decision to have a career in the accounting field. The failure of not having a career choice in line with the accounting students' knowledge is basically affected by the framing through the students' perception itself. The effort to comprehend students' behavior in choosing a career becomes the central topic in behavioral research in the accounting field. Unlike the prior research, it focuses on testing by combining internal factors: the students' behavior aspect in the satisfaction perspective and perception, and the external element that is the learning environment, which affects intent.

The research's additional point is combining the learning environment variables, students' perception, satisfaction, and career choice within one single model. Students' career choices can be affected not only by intrinsic variables such as satisfaction and students' perception but also by extrinsic variables and the learning environment. So far, the research concerning factors affecting career choice in the accounting field has focused on investigating outside elements covering satisfaction and work benefits, career path, and position (Owusu et al., 2018; Wen et al., 2018). The research respondents are accounting students from some universities in Indonesia; DKI Jakarta, West Java, East Java, and Central Java. This research examines whether internal factors, perception and student satisfaction, and external factors, learning environment, become the dominant predictor over career choice as professional accountants.

Theory of Reasoned Action (TRA), which was later developed to Theory of Planned Behavior (TPB), is the most employed theory in research to discover the students' main choice in deciding, including career choice (Tognazzo, Gianecchini, \& Gubitta, 2017). Behavioral control of TPB refers to people's perception of students' ability to have an intent to do an action (Bekoe et al., 2018; Lee \& Schmidt, 2014). TPB thinking framework, which is used in this research, examines students' perception of accounting subjects and investigates factors that support their intention to have accounting as the main subject (Bekoe et al., 2018).

Prapaskah, Brown, and Hacket introduced Social Cognitive Career Theory (SCCT) in 1994 to clarify factors that affect someone's choice ( $\mathrm{Ng}$ et al., 2017). This theory emphasizes the effort to understand and predict individual behavior patterns, which later influence students' interest in their job and education, choices making process, career persistence and performance, and their satisfaction and welfare (Tran \& Von Korflesch, 2016). This matter then explains three interrelated aspects in career development: (1) how academic interest and career development, (2) how education and career choice are made, and (3) how academic and career success is gained. This theory combines several concepts: interest, ability/ competency, values, and environmental factors, which have existed in former career theory and have been revealed to influence career development (Sheu \& Phrasavath, 2019). SCCT has been often used in prior studies to predict the factors that determine individual career choice related to the decision-making process in choosing career, behavior, and environmental factor, which is seen as the main element that affects the process (Dong, Hung, \& Cheng, 2016).

The learning environment has been defined as the existing elements interacting with students in a high education institution. This covers education aspects through a set of learning curriculum, physical and social environment, and psychology in which students are involved. It is considered to play an essential role in developing both their professional and their morals. An excellent and effective learning environment is not limited to communication skills, knowledge, credibility, and teacher readiness, contributing to teaching excellence. Otherwise, it is the one that prepares students for future professional lives and contributes to personal and psychosomatic development and social welfare (Shrestha et al., 2019).

Education quality impacts curriculum quality, teaching-learning reflection, and the development of students' results as practice (Shrestha et al., 2019). The education system's primary purpose is to enhance knowledge, skills, and performance to produce competitive graduates. Cieślik and van Stel (2017) have affirmed in their research that a learning environment needs to fit students' needs in the future to raise their motivation and gain their success. Accounting students usually think that accounting is just knowledge to report and analyze corporate financial transactions. A proper curriculum, teaching method, and learning method are required to reach the learning goal. Furthermore, students can also benefit from extracurricular in university to build their skills and experience (Hatane et al., 2020).

The learning environment is the most visited place in the context of teaching and learning. Automatically each subject involved in the learning environment, such as lecturers and friends, has an important role in building the atmosphere of the learning environment. Students will reflect on the learning environment. When the learning environment in accounting education is not pleasant, it will affect students' psychology in imagining a workplace in the accounting field. Then in TPB itself, it is clarified that intention to do a particular action refers to the person's perception towards the activity itself (Bekoe et al., 2018; Lee \& Schmidt, 2014). For this reason, TPB is employed in this research to test students' perception of accounting majors in terms of choosing a future career. 


\section{METHODS}

TPB concept, the learning environment factor in Foong and Khoo's (2015) research, can also influence students' intention to choose a career in accounting. A great learning environment will bring the perception that the professional field in which they are studying now will be a great profession too. In other words, students' satisfaction with their major is affected by the learning environment. Belongs to this statement, it can be said that students will feel satisfied through the right learning environment. As in introductory psychology, someone will feel satisfied with the right environment, except for the learning environment. This eventually leads to making hypothesis:

H1: Learning environment influences students' perception of a career in the accounting field.

H2: Learning environment influences students' intention to choose a career-related in the accounting field.

H3: Learning environment influences students' satisfaction.

Good accounting perception from students' point of view will generate interest rise in accounting as the primary chosen major. It eventually results in an increasing number of accounting significant and benefit accounting profession since it raises diversity and raises the quality of accounting major (Maas et al., 2013). The presence of students' accurate perception of the profession related to accounting is an essential matter to be developed by the accounting department since that matter can help achieve the department goal of increasing students' interest and intention to take accounting major (Rudiyanto \& Widasari, 2018).

Students with a business background generally have a positive perception of accounting as a career compared to those with no business background (Bekoe et al., 2018). The forming of students' perception of the accountant profession denotes that teachers and lecturers need to emphasize the accounting profession's qualities, for instance, honesty, trust, ethic, and excellence, when having new intake students (Lee \& Schmidt, 2014). Positive perception can affect students' interest in having an accounting career as accountant graduates who are excellent and successful (Hatane et al., 2020).

Moreover, teachers' and lecturers' roles can alter students' perceptions of knowledge. More students' perception is often considered the foundation of students' thinking to plan and determine which path to take next. After being influenced by the learning environment, the accountant profession's perception becomes essential in determining students' intention to choose a career related to the accounting field. Failure to choose a career in line with the accounting study background is affected by the students' perception. The perception refers to satisfaction, which is formed after passing the learning time. This satisfaction appears from someone's basic encouragement related to priority to enjoy life, and having fun becomes a priority (Dalci \& Özyapici, 2018). Expectancy felt and experience gained by students can be in line so that students can declare satisfaction. The examined data show that students who chose their major due to their intrinsic motivation (interest in the field of study) are likely satisfied with their study experience (Soria \& Stebleton, 2013). Besides, extrinsic motivation is positively connected to satisfaction, including students' motivation to choose a major. The chosen major gives them time for other activities, prepares them for a satisfying career and continuing study, and grants them international opportunities (Soria \& Stebleton, 2013). Through SCCT itself, students' perception is described to influence careers. So, satisfaction leads to mindset shaping towards career intention in the accounting field. Relying on this point, here is the formulated hypothesis:

H4: Students' perception of a career in the accounting field affects students' satisfaction.

H5: Students' perception towards a career in the accounting field affects students' intention to choose a career in the accounting field.

Kazi and Akhlaq (2017) have stated that career choice is one of the dilemmas and the biggest challenge in each student's life since it involves and influences many interrelated factors complicatedly, so that making a decision is not an easy task. Career choice is a preliminary plan which can affect most of an individual career path in the future (Thing \& Jalaludin, 2018). A suitable career can determine someone's welfare and satisfaction. Furthermore, career choice can be made upon ambition, interest, and goal to be achieved (Doo \& Park, 2019). Choosing a great career can help someone reach success and happiness, while a bad career choice leads to failure and disappointment.

Schoenfeld, Segal, and Borgia (2017) have explored how accounting students' career intention is affected by result expectancy factors, such as job availability and high earning related to students' intention. In this research, career choice refers to whether an accounting student will pursue a career in the accounting field after graduating. For several reasons, accounting is perceived as an exciting career; one of its causes is that accounting is one of the jobs that offer a good opportunity to work in many sectors and industries. The accounting field can cover auditing, tax, financial accounting, finance, and others (Ng et al., 2017).

Students' satisfaction refers to the satisfaction and experience over their major, especially of particular service; in this case, they evaluate their experience as individuals. Doo and Park (2019) have stated that satisfaction over academics related to the learning quality determines individuals' faith or selfconfidence concerning their ability to decide and choose a career. Therefore, here is the hypothesis: 
H6: Students' satisfaction affects students' intention to choose a career in the accounting field.

The research focuses on examining the influence of learning environment factors, satisfaction, perceptions, and student intentions in choosing a career path. The research places satisfaction and perception as mediating variables. To test the hypothesis in this research, the Structural Equation Model (SEM) or Partial Least Square (PLS) is used. The SEM PLS method uses a measurement model to evaluate the effect between indicators and their constructs, and a structural model is used to analyze the effect between variables.

The research is conducted using the quantitative method by doing surveys through questionnaires. The questionnaire consists of several statements related to variables, which will be tested using a seven-point Likert scale. The questionnaire distribution is done within a month, from early April 2020 to May 2020. The questionnaire is distributed randomly to students by sharing questionnaire links using media online Google Form in universities in Indonesia. The target respondents come from several provinces, such as DKI Jakarta, West Java, East Java, and Central Java. Those cities are selected based on researchers' domiciles. Overall, there are 311 responses from the respondents.

A learning environment is a place where students gain an education, both academically and non-academically. At the same time, career perception is the students' point of view, assessing things related to the accounting field. The feeling of happiness, sadness, or disappointment, which appears when students are in the learning process in the accounting field, is the definition of students' satisfaction. And students' intention to choose a career related to the accounting field is a primary intent of students to determine the career field which will be a future job.

The questionnaire is divided into two parts. First is the respondent's demographic identity. The second part comprises five questions about learning environment variables, four questions related to students' perception, nine questions about students' satisfaction, and four last questions about students' intention to choose a career. The percentage of respondents' demographic is presented in Table 1.

Table 1 Demographic Characteristics of Respondents

\begin{tabular}{llcc}
\hline Character & \multicolumn{1}{c}{ Category } & Frequency & Percentage \\
\hline Gender & Male & 74 & $24 \%$ \\
& Female & 237 & $76 \%$ \\
Semester & Semester 1-2 & 63 & $20,2 \%$ \\
& Semester 3-4 & 97 & $31,2 \%$ \\
& Semester 5-6 & 96 & $31 \%$ \\
& Semester 7-8 & 48 & $15,4 \%$ \\
& Over Semester 8 & 7 & $2,2 \%$ \\
University & Public University & 55 & $17,7 \%$ \\
Type & & & \\
\hline
\end{tabular}

Table 1 Demographic Characteristics of Respondents (Continued)

\begin{tabular}{|c|c|c|c|}
\hline Character & Category & Frequency & Percentage \\
\hline & $\begin{array}{l}\text { Private } \\
\text { University }\end{array}$ & 235 & $75,6 \%$ \\
\hline & $\begin{array}{l}\text { Public Vocational } \\
\text { (polytechnic/ } \\
\text { academy) }\end{array}$ & 14 & $4,5 \%$ \\
\hline & $\begin{array}{l}\text { Private } \\
\text { Vocational } \\
\text { (polytechnic/ } \\
\text { academy) }\end{array}$ & 7 & $2,3 \%$ \\
\hline \multirow[t]{8}{*}{ Major } & $\begin{array}{l}\text { Business } \\
\text { Accounting }\end{array}$ & 158 & $50,8 \%$ \\
\hline & Tax Accounting & 43 & $13,9 \%$ \\
\hline & $\begin{array}{l}\text { International } \\
\text { Accounting }\end{array}$ & 27 & $8,7 \%$ \\
\hline & $\begin{array}{l}\text { Public Sector } \\
\text { Accounting }\end{array}$ & 1 & $0,3 \%$ \\
\hline & $\begin{array}{l}\text { Financial } \\
\text { Accounting and } \\
\text { Syariah }\end{array}$ & 15 & $4,8 \%$ \\
\hline & $\begin{array}{l}\text { Auditing } \\
\text { Accounting }\end{array}$ & 11 & $3,5 \%$ \\
\hline & $\begin{array}{l}\text { Information } \\
\text { System } \\
\text { Accounting }\end{array}$ & 3 & $1 \%$ \\
\hline & Others & 53 & $17 \%$ \\
\hline
\end{tabular}

\section{RESULTS AND DISCUSSIONS}

Data analysis of the research uses Partial Least Square (PLS) to test validity, reliability, and hypotheses. Using PLS aims to explain the relationship between the dependent variable $(\mathrm{Y})$ and the independent variable (X). There are two model analyses of the collected data, the outer model to test validity and reliability and the inner model to test the relation between several variables. PLS can project information from data $\mathrm{X}$ to some latent variables to confirm that the first component is the most relevant in predicting variable Y. Therefore, PLS is selected as the testing method. In the research, there is one independent variable, the learning environment, and two intervening variables, students' perception and students' satisfaction. Cook and Forzani (2018) have stated that PLS regression is an effective method to predict a large number.

Next, the research has two criteria to assess convergent validity: the outer model and the square root of Average Variance Extracted (AVE). The outer model and square root AVE measuring have a standard of more than 0,5. The next thing is discriminant validity, which is how far a particular construct can differentiate itself from the others. In this case, crossloading can be employed to assess the adequacy of discriminant validity. On the one hand, composite reliability is used to measure the excellence of internal consistency, added with Cronbach's alpha to have 
more significant scoring criteria with more than 0,7 . On the other hand, the inner model covers model fit, path coefficient, coefficient of determination $\left(\mathrm{R}^{2}\right)$, effect size $\left(\mathrm{f}^{2}\right)$, and Stone-Geisser test $\left(\mathrm{Q}^{2}\right)$. The score criteria of $\mathrm{R}^{2}$ measurement are $0,70,0,50$, and 0,25 for dependent variables, from big to small, respectively. The testing of model fit in Table 2 reveals that the model has been accepted because its minimum value has reached the acceptable range.

Table 3 presents respondents' scores on the researched variables. Observing the mean score of more than 3,40 indicates that the respondents' responses over LEARN, PERS, SATS, and INCM variables are pretty high. The overall range score above 50 percent can be indicated that the mean can represent respondents' opinions. Moreover, the standard deviation value of each variable ranging from 0,95 to 1,69 is considered low, which means the respondents answer the questions with low diversity. While Table 4 shows that each indicator has a higher loading value at each measured construct than the loading value at other constructs. This confirms that the tested construct has ample validity of discriminant. Table 5 shows the values of the measurement model in terms of inter construct correlation. The result can be concluded that the value of AVE square root or

Table 2 Model Fit and Quality Indices

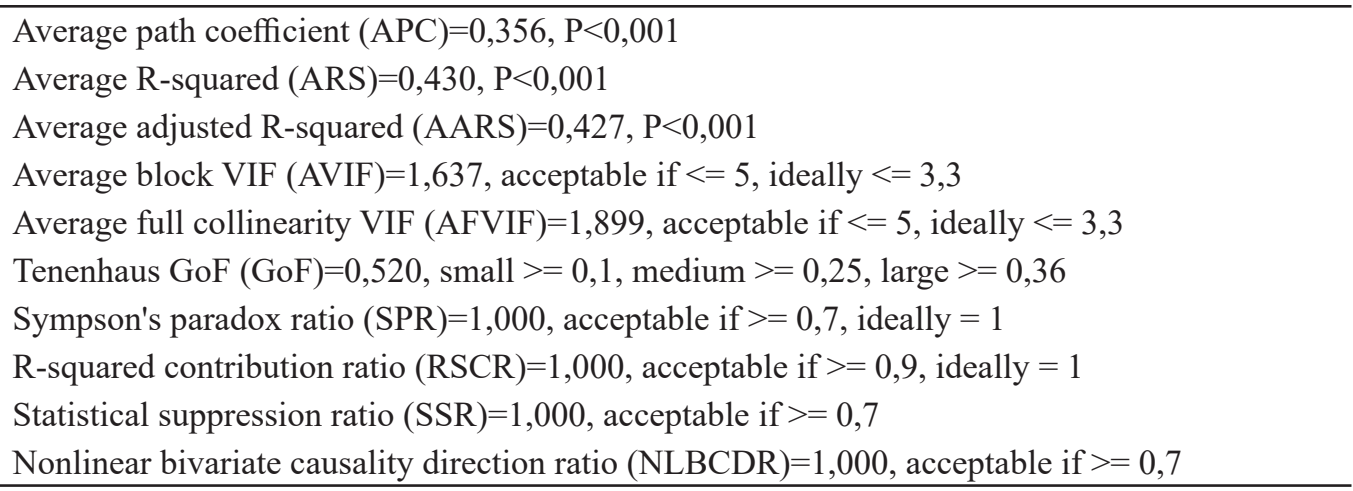

Table 3 Indicators' Mean, Range, and Standard Deviation

\begin{tabular}{lccc}
\hline \multicolumn{1}{c}{ Indicator } & Total Mean & Range (\%) & SD \\
\hline LEARN1 & 5,73 & $86 \%$ & 1,03 \\
LEARN2 & 6,09 & $86 \%$ & 0,95 \\
LEARN3 & 5,49 & $86 \%$ & 1,24 \\
LEARN4 & 5,64 & $86 \%$ & 1,17 \\
LEARN5 & 5,93 & $86 \%$ & 1,06 \\
PERS1 & 5,56 & $86 \%$ & 1,31 \\
PERS2 & 6,3 & $86 \%$ & 1 \\
PERS3 & 5,22 & $86 \%$ & 1,22 \\
PERS4 & 5,74 & $86 \%$ & 1,2 \\
SATS1 & 6,13 & $71 \%$ & 1,05 \\
SATS2 & 6,1 & $57 \%$ & 1,03 \\
SATS3 & 5,86 & $71 \%$ & 1,1 \\
SATS4 & 5,88 & $86 \%$ & 1,19 \\
SATS5 & 5,71 & $71 \%$ & 1,13 \\
SATS6 & 5,27 & $86 \%$ & 1,47 \\
SATS7 & 5,31 & $86 \%$ & 1,24 \\
SATS8 & 5,17 & $86 \%$ & 1,46 \\
SATS9 & 5,55 & $86 \%$ & 1,31 \\
INCM1 & 5,18 & $86 \%$ & 1,6 \\
INCM2 & 5,19 & $86 \%$ & 1,59 \\
INCM3 & 5,25 & $86 \%$ & 1,46 \\
INCM4 & 4,88 & $86 \%$ & 1,69 \\
\hline
\end{tabular}

LEARN $=$ Learning Environment, PERS $=$ Student Perception, SATS $=$ Student Satisfaction, INCM = Intention to Choose Accounting Major 
diagonal value is more than 0,50 . This value describes convergent validity or constructs, which explains more than half of its variant indicators. Then, each composite reliability value and Cronbach's alpha have reached around 0,7 , and therefore this value is accepted. So, the research model is proven reliable. Table 6 displays the effect size for the path coefficient. All values in the following table are more than 0,02, which means that they have the adequate effect of being confirmed relevant from a practical perspective view.

Figure 1 explains the model applied by SEM. Beta coefficient $(\beta)$ represents the strength relation

Table 4 Loading and Cross Loading Value

\begin{tabular}{|c|c|c|c|c|c|c|}
\hline & LEARN & PERS & SATS & INCM & SE & P Value \\
\hline LEARN1 & 0,850 & 0,060 & $-0,105$ & 0,001 & 0,050 & $<0,001$ \\
\hline LEARN2 & 0,792 & 0,113 & $-0,074$ & $-0,047$ & 0,050 & $<0,001$ \\
\hline LEARN3 & 0,723 & 0,013 & $-0,075$ & 0,041 & 0,051 & $<0,001$ \\
\hline LEARN4 & 0,800 & $-0,119$ & 0,146 & 0,022 & 0,050 & $<0,001$ \\
\hline LEARN5 & 0,830 & $-0,067$ & 0,103 & $-0,013$ & 0,050 & $<0,001$ \\
\hline PERS1 & $-0,017$ & 0,796 & $-0,092$ & 0,116 & 0,050 & $<0,001$ \\
\hline PERS2 & 0,088 & 0,763 & $-0,071$ & $-0,147$ & 0,050 & $<0,001$ \\
\hline PERS3 & $-0,060$ & 0,738 & 0,003 & $-0,038$ & 0,051 & $<0,001$ \\
\hline PERS4 & $-0,011$ & 0,817 & 0,154 & 0,058 & 0,050 & $<0,001$ \\
\hline SATS1 & 0,477 & 0,229 & 0,617 & $-0,154$ & 0,052 & $<0,001$ \\
\hline SATS2 & 0,189 & 0,303 & 0,706 & $-0,194$ & 0,051 & $<0,001$ \\
\hline SATS3 & 0,123 & 0,230 & 0,784 & $-0,259$ & 0,050 & $<0,001$ \\
\hline SATS4 & $-0,014$ & 0,070 & 0,849 & $-0,086$ & 0,050 & $<0,001$ \\
\hline SATS5 & $-0,060$ & 0,027 & 0,854 & $-0,078$ & 0,050 & $<0,001$ \\
\hline SATS6 & $-0,243$ & $-0,270$ & 0,787 & 0,227 & 0,050 & $<0,001$ \\
\hline SATS7 & $-0,064$ & $-0,113$ & 0,746 & 0,040 & 0,051 & $<0,001$ \\
\hline SATS8 & $-0,200$ & $-0,333$ & 0,753 & 0,371 & 0,050 & $<0,001$ \\
\hline SATS9 & $-0,089$ & $-0,086$ & 0,815 & 0,106 & 0,050 & $<0,001$ \\
\hline INCM1 & $-0,001$ & $-0,078$ & $-0,044$ & 0,884 & 0,049 & $<0,001$ \\
\hline INCM2 & $-0,001$ & $-0,157$ & $-0,018$ & 0,895 & 0,049 & $<0,001$ \\
\hline INCM3 & 0,003 & 0,387 & 0,020 & 0,643 & 0,051 & $<0,001$ \\
\hline INCM4 & $-0,000$ & $-0,048$ & 0,050 & 0,830 & 0,050 & $<0,001$ \\
\hline
\end{tabular}

Table 5 Correlation Between 1 Versus with sq. rts. from AVEs, Composite Reliability, and Cronbach's Alpha

\begin{tabular}{lcccccc}
\hline & LEARN & PERS & SATS & INCM & Composite Reliability & Cronbach's Alpha \\
\hline LEARN & 0,800 & 0,546 & 0,671 & 0,489 & 0,899 & 0,859 \\
PERS & 0,546 & 0,779 & 0,521 & 0,594 & 0,861 & 0,784 \\
SATS & 0,671 & 0,521 & 0,771 & 0,328 & 0,929 & 0,913 \\
INCM & 0,489 & 0,594 & 0,328 & 0,819 & 0,889 & 0,831 \\
\hline
\end{tabular}

Table 6 Effect Size for Path Coeffient

\begin{tabular}{lcccc}
\hline & LEARN & PERS & SATS & INCM \\
\hline LEARN & - & - & - & - \\
PERS & 0,313 & - & - & - \\
SATS & 0,452 & 0,098 & - & - \\
INCM & 0,129 & 0,288 & 0,010 & - \\
\hline
\end{tabular}


among latent variables linked with the arrow. All of the results are significant with $p<0,01$ unless, for variables SATS on INCM with $\mathrm{p}=0,31$, it is insignificant.

Figure 1 PLS-Based Structural Equation Model

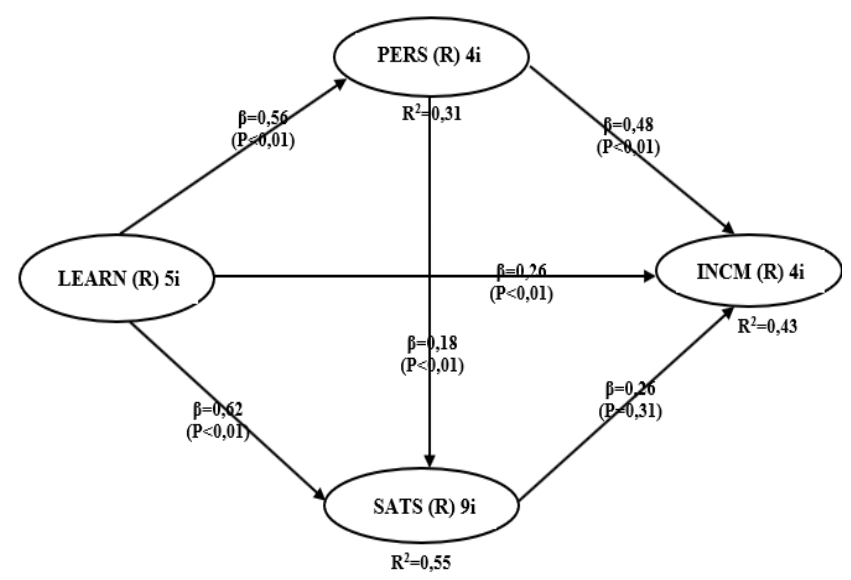

Table 7 displays both direct and indirect effects on the tested variables. Based on the counting result, $\mathrm{R}^{2}$ values on PERS and SATS are 0,31 and 0,55, respectively. This points out that $31 \%$ of variation change on PERS variable can be clarified with LEARN variable which has beta coefficient as much 0,56 , and $55 \%$ variation change on SATS variable which is represented by the value of LEARN beta coefficient of 0,62 . The direct effect on the INCM variable is detailed through variable LEARN, PERS, and SATS as much 0,43 with each has beta coefficient 0,$26 ; 0,48$; and 0,03 . Next, $R^{2}$ is used to count the Goodness of Fit $(\mathrm{GOF})$ as follows $\mathrm{Q}^{2}=1-((1-0,31) \times(1-0,43) \mathrm{x}$ $(1-0,55))=82 \%$. This score percentage shows that the direct and indirect effect of LEARN, PERS, and SATS over INCM is $82 \%$.

The research findings show that the learning environment positively influences students' intention to have a career in the accounting field with a value $\beta=0,26$, and $p$-value $<0,01$. The learning environment becomes students' place to interact with the elements in the education system which are developed by high education and strongly affect students' intention to have a career related to the accounting field (Foong \& Khoo, 2015; Hatane et al., 2020; James \& Yun, 2018; Thygesen et al., 2020; Waheed, Kaur, \& Kumar, 2016). Factors in a learning environment significantly influence students' intention to have a career in the accounting field, as these research findings are curriculum, lecturer competency, and intensity of lecturer and student interaction. Dean et al. (2018) have emphasized the contemporary accounting curriculum constructed with an integrative approach so that students comprehend how accounting role in society and later get influenced to have a career in the accounting field.

The research also proves the existence of a significantly positive influence of the learning environment towards students' satisfaction with a value of 0,62 for $\beta$ and $<0,01$ for $p$-value. The research finding is confirmed by several pieces of research which collectively affirm that the learning environment influences students' satisfaction. Some research, such as the one from Dalci \& Özyapici (2018), supports the research finding that learning environment through experiencing lecture, facility, and service provided by the university, curriculum, and qualified lecturer are the factors that affect students' satisfaction. Rocconi, Liu, and Pike (2020) have also agreed with the research finding that students' satisfaction and success are heavily influenced by the learning environment.

The research also proves the existence of a significantly positive influence of the learning environment towards students' satisfaction with a value of 0,62 for $\beta$ and $<0,01$ for $p$-value. The research finding is confirmed by several pieces of research which collectively affirm that the learning environment influences students' satisfaction. Some research, such as the one from Dalci \& Özyapici (2018), supports this research finding that learning environment through

Table 7 Inner Model Result

\begin{tabular}{lcc}
\hline \multicolumn{1}{c}{ Path Relationship } & Direct Effect & Indirect Effect \\
\hline LEARN -> PERS & $0,56(\mathrm{P}<0,01)$ & - \\
PERS -> INCM & $0,48(\mathrm{P}<0,01)$ & - \\
LEARN -> INCM & $0,26(\mathrm{P}<0,01)$ & - \\
SATS -> INCM & $0,03(\mathrm{P}=0,31)$ & - \\
PERS -> SATS & $0,18(\mathrm{P}<0,01)$ & - \\
LEARN -> SATS & $0,62(\mathrm{P}<0,01)$ & - \\
LEARN -> PERS -> SATS & - & $0,102(\mathrm{P}=0,005)$ \\
LEARN -> PERS -> INCM & - & $0,286(\mathrm{P}<0,001)$ \\
LEARN -> SATS -> INCM & - & $0,017(\mathrm{P}=0,329)$ \\
PERS -> SATS -> INCM & - & $0,005(\mathrm{P}=0,451)$ \\
LEARN -> PERS -> SATS -> INCM & - & $0,003(\mathrm{P}=0,466)$ \\
\hline
\end{tabular}


experiencing lecture, facility, and service provided by the university, curriculum, and qualified lecturer are the factors that affect students' satisfaction. Rocconi, Liu, and Pike (2020) have also agreed with this research finding that students' satisfaction and success are heavily influenced by the learning environment.

The research also does an intervening test for students' perception factors about the accounting field's learning environment and career intention. The $\beta$ value and $p$-value are 0,102 and $<0,005$, respectively. And the intervening test for students' perception about the learning environment and career intention in the accounting field with $\beta=0,286$ and $p$-value $<$ 0,001 . The research finding clarifies that the learning environment can influence students' perception of not only getting satisfaction but also having a career in the accounting field. A learning environment with a set of curriculum, competent lecturers, and interactive learning methods as indicators in the research can be information that can build trust, shape students' perception, and eventually affect students' satisfaction and intention to have a career in accounting field. This statement is in line with Flamini et al. (2017), who further explains that students who are interested in certain career are at risk of being discouraged by negative perceptions. The testing of another intervening variable in this research is done for satisfaction factor in relation with perception and intention to have a career in the accounting field with a value of $\beta=0,017$ and $p$-value $<0,329$, and the satisfaction over learning environment and career intention is with $\beta$ values as much 0,005 and $p$-value $<0,451$. However, those two testing results fail in proving that satisfaction can affect the relation between perception and learning environment over career intention in the accounting field. Because of this, high students' satisfaction cannot raise students' intention to have a career in the accounting field; it is the students' perception, the strongest factor in forming students' intention, that shapes their intention have a career in accounting. Thus, it is strongly suggested that study programs of accounting and accounting profession institutions maintain students' positive perception of accounting's role in business development.

From the research, there is the fact that the effect of students' perception on the intention to have a career in the accounting field is as strong as if it is directly from the learning environment to the intention to have a career in the accounting field without intervening variable.

\section{CONCLUSIONS}

The learning environment becomes one of the interesting research objects which can contribute to education system improvement held by a university. Overall, the hypothesis formulated in the research confirms TPB and SCCT. TPB answers how students' perception, which is shaped based on information about the accountant profession, directly and indirectly, can influence students' intent to choose a career in the accountant field. So is SCCT, in which students combine personal factors, perception and satisfaction, and learning environment factor, which can direct students to choose a career in the accounting field and make achievements as expected. Each of the test findings emphasizes how important high education and association of accountant profession to enhance students' belief through introducing accountant profession early and sustainably to accounting students to form perception which triggers deep interest to have a career in the accounting field. The findings of the research confirm that the formation of the learning environment with the satisfying quality of accounting knowledge can play an important role in accounting students' study performance. A good learning environment can establish a positive perception for accounting students so that the positive perception can influence students' readiness over the future challenge and determine their intent to choose a career for the future.

The research is expected to benefit the related parties to create strategies to enhance the quality and quantity of professional accountants in Indonesia. However, based on the demography of the questionnaire distribution, which is only in a few provinces in Indonesia, for future research, the researchers hope there will be research that covers the whole provinces in Indonesia or even outside Indonesia. The variables used in the research are dynamic so that the differences in region, time, and research object can generate different findings as well. GOF 82 percent indicates that 28 percent of factors outside the variables used in the research can affect the research findings. Since each profession has its uniqueness, it is also expected that future research can apply this framework to the different professions as a learning environment, perception, and satisfaction are possibly found in other professions.

The learning environment can be shaped well when students are actively involved in the discussion of current issues. It means that in the lecturing, students can feel a positive learning environment when the lecturer exposes the latest issue in business and accounting. So, in other words, lecturers are expected to keep updated with the latest news which is relevant to the subject they lecture. Also, lecturers can urge the students in their class to read the latest news relevant to business and accounting. This positive learning environment will enhance students' perception of having a career in the accounting field. When discussing the current issue in business, lecturers should be capable of directing students to think about the accountant role in business related to the issue.

\section{ACKNOWLEDGEMENT}

The research got an internal grant funded by the Institute of Research and Community Service. 


\section{REFERENCES}

Bekoe, R. A., Owusu, G. M. Y., Ofori, C. G., Essel-Anderson, A., \& Welbeck, E. E. (2018). Attitudes towards accounting and intention to major in accounting: A logistic regression analysis. Journal of Accounting in Emerging Economies, 8(4), 459-475. https://doi. org/10.1108/JAEE-01-2018-0006.

Cieślik, J., \& van Stel, A. (2017). Explaining university students' career path intentions from their current entrepreneurial exposure. Journal of Small Business and Enterprise Development, 24(2), 313-332. https://doi.org/10.1108/JSBED-09-2016-0143.

Cook, R. D., \& Forzani, L. (2018). Big data and partial least-squares prediction. Special Issue on Big Data and the Statistical Sciences, 46(1), 62-78. https:// doi.org/10.1002/cjs.11316.

Dalci, İ., \& Özyapici, H. (2018). Cultural values and students' intentions of choosing accounting career. Journal of Financial Reporting and Accounting, 16(1), 179-196. https://doi.org/10.1108/JFRA-092016-0072.

Dean, B. A., Perkiss, S., Simic Misic, M., \& Luzia, K. (2018). Transforming accounting curricula to enhance integrative learning. Accounting and Finance, 60(3), 2301-2338. https://doi.org/10.1111/ acfi. 12363.

Dong, T. P., Hung, C. L., \& Cheng, N. C. (2016). Enhancing knowledge sharing intention through the satisfactory context of continual service of knowledge management systems. Information Technology and People, 29(4), 807-829. https://doi.org/10.1108/ ITP-09-2014-0195.

Doo, M. Y., \& Park, S. H. (2019). Effects of work value orientation and academic major satisfaction on career decision-making self-efficacy. Higher Education, Skills and Work-Based Learning, 9(4), 550-562. https://doi.org/10.1108/HESWBL-09-2018-0088.

Flamini, T., Matthews, N. R., Castle, G. S., \& JonesWilliams, E. M. (2017). Medical student and psychiatrist perceptions towards a psychiatric career. Mental Health Review Journal, 22(4), 315323. https://doi.org/10.1108/MHRJ-03-2017-0015.

Foong, S. Y., \& Khoo, C. H. (2015). Attitude, learning environment and current knowledge of accounting students in Malaysia. Journal of Accounting in Emerging Economies, 5(2), 202-221. https://doi. org/10.1108/JAEE-07-2012-0030.

Friedman, T. (2016). Thank you for being late: An optimist's guide to thriving in the age of accelerations. New York: Farrar, Strauss and Girous.

Gardner, P. (2017). Flourishing in the face of constant disruption: Cultivating the t-professional or adaptive innovator through WIL. International Perspectives on Education and Society, 32, 69-81. https://doi. org/10.1108/S1479-367920170000032004.

Hatane, S. E., Setiono, F. J., Setiawan, F. F., Semuel, H., \& Mangoting, Y. (2020). Learning environment, students' attitude and intention to enhance current knowledge in the context of choosing accounting career. Journal of Applied Research in Higher
Education, 13(1), 79-97. https://doi.org/10.1108/ JARHE-06-2019-0156.

James, M., \& Yun, D. (2018). Exploring student satisfaction and future employment intentions: A case study examination: is there a link between satisfaction and getting a job? Higher Education, Skills and Work-Based Learning, 8(2), 117-133. https://doi. org/10.1108/HESWBL-03-2017-0019.

Kazi, A. S., \& Akhlaq, A. (2017). Factors affecting students' career choice. Journal of Research and Reflections in Education, 1(2), 187-196.

Lee, W. E., \& Schmidt, D. (2014). A multigroup analysis of students' intention to major in accounting before, during, and after the recession: Emergence of a professional ethics perception. Advances in Accounting Education: Teaching and Curriculum Innovations, 15, 33-57. https://doi.org/10.1108/ S1085-462220140000015000.

Maas, J. D., Keeling, K. O., Michenzi, A. R., \& Bossle, F. X. (2013). Using an accounting fair to increase students' favorable perceptions of accounting and interest in the accounting major. Advances in Accounting Education: Teaching and Curriculum Innovations, 14, 1-16. https://doi.org/10.1108/ S1085-4622(2013)0000014007.

Ng, Y. H., Lai, S. P., Su, Z. P., Yap, J. Y., Teoh, H. Q., \& Lee, H. (2017). Factors influencing accounting students' career paths. Journal of Management Development, 36(3), 319-329. https://doi.org/10.1108/JMD-112015-0169.

Owusu, G. M. Y., Essel-Anderson, A., Ossei Kwakye, T., Bekoe, R. A., \& Ofori, C. G. (2018). Factors influencing career choice of tertiary students in Ghana: A comparison of science and business majors. Education and Training, 60(9), 992-1008. https://doi.org/10.1108/ET-04-2017-0050.

Rocconi, L. M., Liu, X., \& Pike, G. R. (2020). The impact of person-environment fit on grades, perceived gains, and satisfaction: An application of Holland's theory. Higher Education, 80, 857-874. https://doi. org/10.1007/s10734-020-00519-0.

Rudiyanto, \& Widasari, E. (2018). Factors that influence student intentions towards accounting major in Indonesia. Proceeding International Seminar on Accounting for Society, 1(1), 146-154.

Schoenfeld, J., Segal, G., \& Borgia, D. (2017). Social cognitive career theory and the goal of becoming a certified public accountant. Accounting Education, 26(2), 109-126. https://doi.org/10.1080/09639284.2 016.1274909 .

Sheu, H. B., \& Phrasavath, L. (2019). Social cognitive career theory: Empirical evidence and cross-cultural applications. In Contemporary Theories of Career Development (pp. 47-60). London: Routledge. https://doi.org/10.4324/9781315276175-6.

Shrestha, E., Mehta, R. S., Mandal, G., Chaudhary, K., \& Pradhan, N. (2019). Perception of the learning environment among the students in a nursing college in Eastern Nepal. BMC Medical Education, 19(1), 1-7. https://doi.org/10.1186/s12909-019-1835-0.

Soria, K. M., \& Stebleton, M. (2013). Major decisions: 
Motivations for selecting a major, satisfaction, and belonging. NACADA Journal, 33(2), 29-43. https:// doi.org/10.12930/nacada-13-018.

Thing, O. G., \& Jalaludin, D. (2018). Career path in accounting: What are the drivers? International Academic Journal of Accounting and Financial Management, 5(2), 161-177.https://doi.org/10.9756/ iajafm/v5i2/1810024.

Thygesen, H., Gramstad, A., Åsli, L. A., Stigen, L., Magne, T. A., Carstensen, T., \& Bonsaksen, T. (2020). Associations between learning environment factors and student satisfaction among occupational therapy students. Irish Journal of Occupational Therapy, 48(2), 91-100. https://doi.org/10.1108/IJOT-102019-0015.

Tognazzo, A., Gianecchini, M., \& Gubitta, P. (2017). Educational context and entrepreneurial intentions of university students: An Italian study. Contemporary Issues in Entrepreneurship
Research, 7, 47-74. https://doi.org/10.1108/S2040724620170000007008 .

Tran, A. T. P., \& Von Korflesch, H. (2016). A conceptual model of social entrepreneurial intention based on the social cognitive career theory. Asia Pacific Journal of Innovation and Entrepreneurship, 10(1), 17-38. https://doi.org/10.1108/apjie-12-2016-007.

Waheed, M., Kaur, K., \& Kumar, S. (2016). What role does knowledge quality play in online students' satisfaction, learning and loyalty? An empirical investigation in an eLearning context. Journal of Computer Assisted Learning, 32(6), 561-575. https://doi.org/10.1111/jcal.12153.

Wen, L., Yang, H., Bu, D., Diers, L., \& Wang, H. (2018). Public accounting vs private accounting, career choice of accounting students in China. Journal of Accounting in Emerging Economies, 8(1), 124-140. https://doi.org/10.1108/JAEE-09-2016-0080. 
APPENDIX

\begin{tabular}{|c|c|c|}
\hline & Item Number & Items \\
\hline Learning Environment & LEARN1 & $\begin{array}{l}\text { Discussion of current issues on accounting, business and other } \\
\text { supporting knowledge are part of the course syllabus. }\end{array}$ \\
\hline \multirow{4}{*}{$\begin{array}{l}\text { Saarce Elsye Hatane, Felicia } \\
\text { Jesslyn Setiono, Fannie Felita } \\
\text { Setiawan, Hatane Semuel, dan } \\
\text { Yenni Mangoting (2020) }\end{array}$} & LEARN2 & $\begin{array}{l}\text { Knowledge of accounting, business and other supporting knowledge } \\
\text { are required competency for accounting graduates. }\end{array}$ \\
\hline & LEARN3 & $\begin{array}{l}\text { Knowledge of accounting, business and other supporting knowledge } \\
\text { often become source of discussion among students. }\end{array}$ \\
\hline & LEARN4 & $\begin{array}{l}\text { My teachers always encourage students to read current issues related } \\
\text { to accounting, business and other supporting knowledge though it is } \\
\text { out/beyond syllabus. }\end{array}$ \\
\hline & LEARN5 & $\begin{array}{l}\text { My teachers have broad knowledge related to accounting, business } \\
\text { and supporting knowledge though it is out/beyond syllabus. }\end{array}$ \\
\hline Career Perception & PERS1 & An accountant is an honest and trustworthy job \\
\hline \multirow{3}{*}{$\begin{array}{l}\text { Krista M. Soria \&Michael } \\
\text { Stebleton (2013); Rudiyanto } \\
\text { \& Ela Widasari (2018) }\end{array}$} & PERS2 & Being an accountant must uphold ethical behavior \\
\hline & PERS3 & Leads to a High Paying Job \\
\hline & PERS4 & Provides International Opportunities \\
\hline Student Satisfaction & SATS1 & Availability of courses for general education or breadth requirements \\
\hline \multirow{8}{*}{$\begin{array}{l}\text { Kee-Cheok Cheong, } \\
\text { Christoper Hill, Yin-Ching } \\
\text { Leong, Chen Zhang, dan } \\
\text { Zheng Zhang (2018) }\end{array}$} & SATS2 & Variety of courses available in your major \\
\hline & SATS3 & Quality of upper-division courses in your major \\
\hline & SATS4 & Availability of courses needed for graduation \\
\hline & SATS5 & Quality of faculty instruction \\
\hline & SATS6 & Quality of lower-division courses in your major \\
\hline & SATS7 & Quality of teaching by graduate student instructors \\
\hline & SATS8 & Opportunities for research experience or to produce creative products \\
\hline & SATS9 & Educational enrichment \\
\hline \multirow{2}{*}{$\begin{array}{l}\text { Intention to Choose } \\
\text { Accounting Career Major } \\
\text { (Career Choice) }\end{array}$} & INCM1 & $\begin{array}{l}\text { I chose this program because I want to be a member of the accounting } \\
\text { profession }\end{array}$ \\
\hline & INCM2 & After graduation I will work in accounting \\
\hline \multirow{2}{*}{ Rudiyanto \& Widasari (2018) } & INCM3 & Being a professional accountant is very prestigious \\
\hline & INCM4 & After I graduate I will continue my higher accounting studies \\
\hline
\end{tabular}

